\title{
Of Sky, Water and Skin: Photographs from a Zanzibari Darkroom
}

\author{
PAMILA GUPTA \\ WISER, University of the Witwatersrand \\ https://orcid.org/0000-0003-1599-1137
}

\begin{abstract}
In this article, I propose to take up the concept and physical space of a photographic 'darkroom' located in Stone Town, Zanzibar, to explore a set of images from the Capital Art Studio (1930-present) collection produced by Ranchhod Oza (190793), and inherited by his son Rohit Oza (1950-). I employ a concept of darkness to read this visual archive differently and propose multiple 'other lives' for a set of images. First, by bringing this African photography collection to light, I am taking it out of the 'dark rooms' of history in one sense and exposing it for interpretation. Second, I focus my lens on the Oza physical darkroom located in the back of the studio on Kenyatta Road in Stone Town, where photographs of a range of Zanzibari persons were both developed and printed and that open up the darkroom as a place of photographic complexity and sensorium, and not just mechanical reproduction. Third, I develop darkness as a form of beauty in certain images of sky, water and skin from this archive that showcase Zanzibar's position as an Indian Ocean island and port city whilst under rule by the Omani Sultanate (1698-1964) and British Protectorate (1890-1963). Fourth, I conceptualise the Zanzibar Revolution of 1964 as a time of visual darkness, which temporarily restricted photographic practices operating in Stone Town under the new Afro-Shirazi political party. Throughout my analysis, I use a framing of 'darkness' to interrogate photography as an aesthetic practice deeply immersed in materialities and metaphors of dark and light, black and white, and as integral to Zanzibar's oceanic islandness.
\end{abstract}

\section{Introduction: Darkness}

So time dismembers the images of our time. Or to put it in an archaeological way, it is as if the details of our lives have accumulated in layers, and now some layers have been displaced by the friction of other events, and bits of contingent pieces still remain, accidentally tumbled about. -

Abdulrazak Gurnah, By the Sea 
Capital Art Studio is the last remaining photography studio in Stone Town, Zanzibar, and the subject of a larger research project.* The idea for approaching this visual archive through the trope of darkness came out of a conference I attended in January 2019 on the theme of literary and cultural darkness that was held in Svalbard, Norway, over five days of atmospheric darkness. Interestingly, it was several key concepts from the Call for Papers (CFP) for this conference that shaped my initial thinking: the appeal of darkness as a place of and for meditation on the visual, a symbol of colonial otherness, an aesthetic choice and thing of beauty, the idea of environmental darkness from light pollution, and finally darkness as a 'central motif and a precondition for creativity.' Equally significant was the affect of rare natural darkness itself - the 'humbling majesty of the polar night' ${ }^{2}$ - that I experienced on this Arctic island and that led me to develop this article in unexpected directions, helping me to draw out what survives or is left over in a set of photographic images. Lastly, it afforded an opportunity to take up the theme of the 2019 University of the Western Cape Visual History workshop, and now special issue of this journal.

Specifically, the theme of 'other lives of the image' that this special issue takes up, provides a productive framing for reading an older visual archive anew, and in creative ways, one that releases them from their archival settings, and asks difficult questions around photography's continuities, metamorphoses, temporalities and spatialities, and of history's remembering, forgetting, and finally, suppression, all tied to politics and aesthetics. Approached in this manner, the theme of darkness becomes a fitting way to enter into the Capital Art Studio collection, as a way to understand the role of a father and son proprietor team that spans 90 years, as African image makers who experienced Zanzibar's tumultuous island history from its heyday as a cosmopolitan Indian Ocean port city through its period of revolution and integration with the African mainland, and its current position on the global tourist island circuit. It is a way of refracting Zanzibar's accumulated layers of history through its extant images, dismembered by time, but still that which remains by chance or accident, a point gestured to in my opening quote by Zanzibari novelist Abdulrazak Gurnah. ${ }^{3}$

As well, such a framing is attuned to the time and space of photography's work, both its potentials and limits; that is, when, where, and how certain images were produced by Ranchhod Oza at his physical studio, including moments of political flourishing and disruption. It is also about the processes by which his son Rohit renarratives certain images and experiences (forgetting some, emphasising others)

\footnotetext{
This article is part of a joint research project with Meg Samuelson, a literary scholar who was previously based at Stellenbosch University and the University of Cape Town and is now at the University of Adelaide. We visited Zanzibar in 2012, 2015 and 2018 and interviewed Rohit Oza, the current proprietor, extensively on a wide range of topics tied to the history of Capital Art Studio (1930-present). Together, we are documenting the everyday practices of a working photography studio in touristic Zanzibar, looking at the studio's larger history (under the proprietorship of his late father Ranchhod Oza, 1930-93), whilst locating many images taken by father and son through conversations with Rohit Oza, and exploring the studio's relationship (past and present) to visual cultures on the island of Zanzibar. Even as we have conducted the research together on this studio, we have been writing our own articles that are tied to specific interests, as well as disciplinary trainings, anthropology and literary studies, respectively.

1 'Darkness 2019', Longyearbyen, Svalbard, 13-17 January 2019, https://darknessconference2019.wordpress.com/. Here I am paraphrasing some of the key elements from the much longer CFP for this conference.

Ibid. Cited from the CFP.

A. Gurnah, By the Sea (London: Bloomsbury Publishing, 2001), 142.
} 
over time, including my conversations with him over three visits to Stone Town, in 2012, 2015 and 2018. ${ }^{4}$ Lastly, the work of photography involves my own anachronistic activation of a selection of Oza images during a very different time and space that transcends the boundaries and borders (of both nationalism and historiography) of Zanzibar itself. It is a process attuned to the theme of (island) darkness, and is generative of other ones - of collecting, preserving, creating dialogue between images that have survived the vicissitudes of time, history and memory ${ }^{5}$ in order to set up this curatorial experiment centred on the 'other lives' of images. ${ }^{6}$ It is an attempt on my part to open them to a different set of performances, meanings, framings, watery reflections, and lived experiences that have the potential to help us think anew about African history and aesthetics, photography and islands.

\section{Part 1: Experiments of the Dark}

Taking Joseph Conrad's 1899 figuration of Africa (or rather the African continent) - also a reference point for the Svalbard conference that I attended on the theme of darkness ${ }^{7}$ - more generally as the heart of darkness (meaning a place of darkness) as a starting point, ${ }^{8}$ I open up this essay with a reminder of the ways in which the discursive darkness of Africa has rendered it generalised, unseen, invisible, undefined. It is here that the visual can perhaps play a crucial role in moving Africa out from under the cover, secrecy and negative connotation of darkness. I reconceptualise Africa instead as (the heart of) lightness, bringing it (and specifically a visual archive) to light and with the potential for a new set of readings and interpretations. It is a form of photographic exposure over a longer longue durée, and an attempt to take a mid twentieth-century African photography collection out of what Patricia Hayes calls the 'dark rooms' of history that are typically tied up with colonial logics and archives. ${ }^{9}$ Instead, I am moving this visual collection into the distinct light (and lighting) of the early twenty-first century, and unmooring this island from its Omani Sultanate and British Protectorate hold and giving it breath and weight once again, in order to hone in on certain material and metaphoric aspects of darkness as saying something else about Capital Art Studio, photography and Zanzibar itself.

4 As noted, Meg Samuelson and I interviewed Rohit Oza on the premises of Capital Art Studio on Kenyatta Road, in Stone Town, Zanzibar on three separate fieldwork visits: 16-23 October 2012, 14-21 July 2015 and 29 May-5 June 2018. Conversations with Rohit Oza are referenced throughout this article - many of these are from a combination of conversations over the three visits as opposed to one specific time/visit to Zanzibar.

5 P. Gupta and T. Adams, 'Vernacular Photography from Africa: Collections, Preservation, Dialogue', Critical Arts, 32, 1, 2018, 1-12. With this special issue, this was one of my first experiments of playing with the Oza visual archive, and reassembling it along different lines in a contemporary moment. See P. Gupta, '(Sensuous) Ways of Seeing in Stone Town, Zanzibar: Patina, Pose, Punctum', Critical Arts, 32, 1, 2018, 59-74.

6 These themes are at the centre of the CFP for the 'Other Lives of the Image' conference and publication. In this introductory section, I have tried to elaborate on what the stakes are in reading for other lives of a set of Oza images from the 1930s to the 1970s, and what they look like in the here and now - Johannesburg, South Africa, in 2020. I would like to thank Patricia Hayes and the two anonymous reviewers for their productive comments in sharpening the depth of my ideas.

7 'Darkness', 2019. The CFP states: 'Both in the past and today, Western colonialism has addressed its own anxieties by projecting them onto the non-European "dark places of the earth," as Conrad puts it in Heart of Darkness (1899).'

8 J. Conrad, Heart of Darkness (London: Blackwood's Magazine, 1899).

9 P. Hayes, 'Photographic Publics and Photographic Desires in 1980s South Africa', Photographies, 10, 3, $2017,303-27$. 
Michelle Wright develops the idea of the 'physics of blackness, ${ }^{10}$ looking for what she calls specific space/time(s) when and where it (blackness) is being imagined, defined, and performed and in what locations (both literal and figurative). Here I will push thinking about the physics of 'darkness' in the same complex ways; doing so implicates a relationship between tropes of blackness and darkness in and for Africa. What happens when we return to the etymology of the word to consider 'dark' as the absence of light, and black as the realisation of that absence? ${ }^{11}$ Is blackness then how we experience darkness? Does this become a possible methodology for how to read this historical photographic collection, to create other lives for those African subjects and objects (found or located) in a set of older images? It is a form of experimentation of the dark.

\section{Part II: Experiments in the Dark}

Capital Art Studio - its name still evokes the grandeur and worldliness of Zanzibar itself. ${ }^{12}$ Ranchhod Oza, newly married, arrived in the newly anointed British Protectorate (since 1890) from Jahangir in Gujarat in 1925 via Zanzibar's 'imperial connections' with British India. ${ }^{13}$ It had taken his parents 28 days on a dhow to cross the Indian Ocean to Zanzibar, Rohit tells me during our first visit with him in 2012. His father, already an avid photographer prior to his departure, discovered a vibrant community of Goan photographers running successful studios, a topic I have written about elsewhere. ${ }^{14}$ After apprenticing with A.C. Gomes \& Sons for five years (192530), ${ }^{15}$ Ranchhod opened his own studio, and made a life for himself as a photographer, husband and father. He would hang out with a gang of photographers, staying up until midnight to develop prints in his very own darkroom, details that Rohit fondly remembers from his childhood, and recounts for me on different occasions. His father would buy paper and fixer from a local Goan photographer and have his postcards printed in the UK and Germany, which he sold in packets of 12. Ranchhod

10 M. Wright, Physics of Blackness: Beyond the Middle Passage Epistemology (Minneapolis: University of Minnesota Press, 2015).

11 https://www.merriam-webster.com/dictionary/dark

12 Stone Town, also known as Mji Mkonwe (Swahili for 'old town'), is the historic centre of Zanzibar and is divided by a creek (now Creek Road) from the newer part of Zanzibar town called Ngambo. Zanzibar is a semi-autonomous region of Tanzania located 30 kilometres off its coast; it is an archipelago that consists of several small islands and two larger ones (Pemba in the north, and Unguja in the south; the latter includes Stone Town). Stone Town is a port city, a site of historical, economic and architectural significance in East Africa, known for its creole culture - a mixing of Arab, Persian, Indian and European elements over a 500-year period. Its population is estimated at slightly less than half a million persons (of the 1.1 million that live in Zanzibar), with Swahili its official language, and Islam its dominant religion. Stone Town was put on the UNESCO world heritage list in 2000; this has helped transform it into a global tourist destination with many aspects of its history and culture heritagised. See P. Gupta, 'Balcony, Door, Shutter: Baroque Heritage as Materiality and Biography in Stone Town, Zanzibar', Vienna Working Papers in Ethnography (VWPE no. 9), Department of Social and Cultural Anthropology, University of Vienna, 2019, www.ksa.univie.ac./vwpe09.

13 T. Metcalf, Imperial Connections: India in the Indian Ocean Arena, 1860-1920 (Berkeley: University of California Press, 2007). Metcalf's point that colonial subjects became 'imperial citizens' in the act of crossing the Indian Ocean is an important one, in that it opened up people like Oza to a more worldly cosmopolitan lived experience.

14 This Goan world of late nineteenth/early twentieth-century photographers included A.C. Gomes, A.P. de Lord, E.C. Dias and the Coutinho Brothers. They catered to Europeans, the Indian merchant class and African elites. For additional historical details, see M. Frenz, Community, Memory, and Migration in a Globalizing World: The Goan Experience, c. 1890-1980 (New Delhi: Oxford University Press, 2014) and P. Gupta, 'The Work of Adornment: Goans at the Frayed Seams of Zanzibari History' (forthcoming 2021).

15 A.C. Gomes opened the Zanzibar studio in 1868 as an offshoot of his Kenya one. See E. Haney, Photography and Africa (London: Reaktion Books, 2010). 

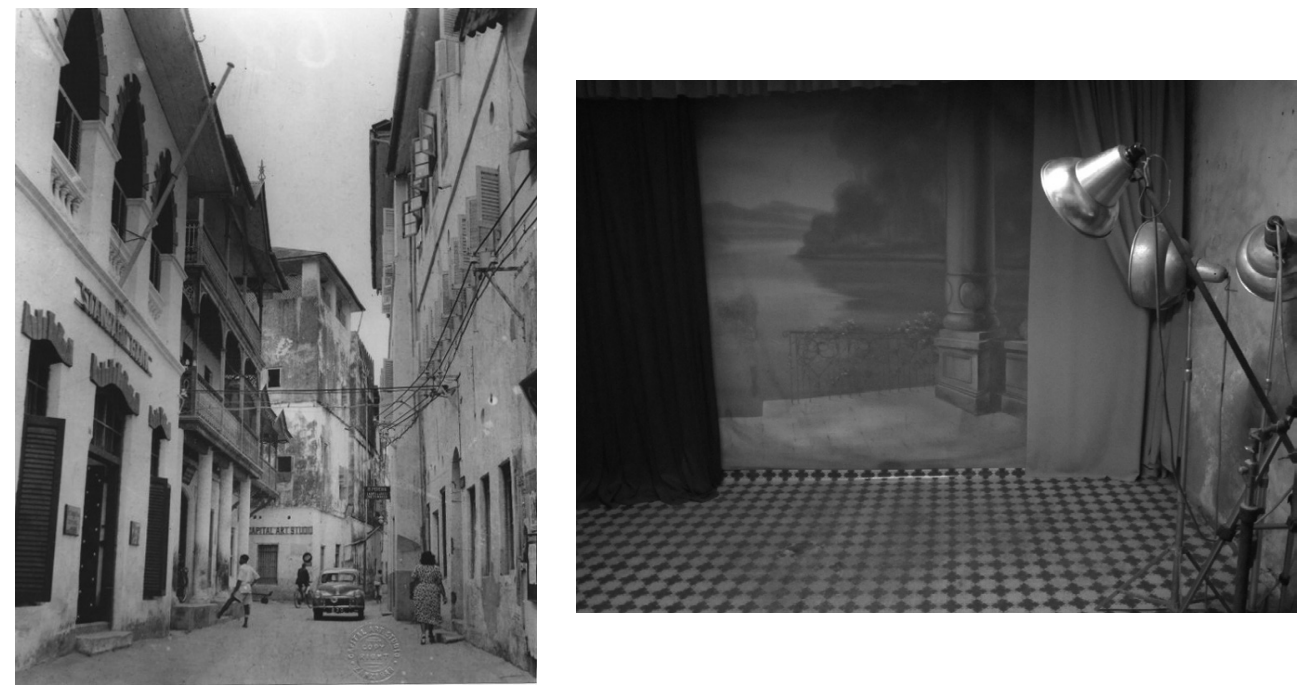

would produce Christmas and Eid cards as well which were on display in the front studio. Rohit tells me how his father was 'talented', an extremely skilled photographer, who knew all the aperture shutter speeds and timings for processing film, both black and white, and colour.

His father was also a fervent film-maker who owned a super eight camera, producing home movies of family events alongside shorts of the Zanzibar Royal Navy, his special interest. Ranchhod invested in several backdrops by mail order from the UK in 1940, that is, right when his business started to stabilise. One of these backdrops was of a nondescript seaside with featured palm trees; another was of balustrades with a view onto a lake, and which is still on display, albeit a bit faded now, in the back part of the studio. ${ }^{16}$ The backdrop abuts a faded and worn black and white chequered flooring pattern that suggests all the feet that stood there, poised to have their photograph taken. Rohit tells me how his father liked to let scenes unfold, take natural photographs even as he experimented with double exposures, and superimpositions later in life. It was Ranchhod who also trained Rohit in darkroom developing and printing when he showed an interest in following his father's profession at a young age. Here I imagine Ranchhod and Rohit, father and son working together, forging a bond over their love of photography in the darkroom, and which was purposely blackened from a bright sun cast from the island light and space of Zanzibar.

In this section, I focus on the physical darkroom of Capital Art Studio that was historically located in the back of the studio on Kenyatta Road in Stone Town, Zanzibar. Even as that darkroom no longer exists today, there is a faded blue curtain

16 Arjun Appadurai has a fascinating short essay on the colonial photographic backdrop as 'sites of epistemological uncertainty about exactly what photographs seek to represent'. See A. Appadurai, 'The Colonial Backdrop-Photography', Afterimage, 24, 5, March-April 1997, n.p. His work on the backdrop as a complex subject parallels my attempt to make the darkroom a subject for further analysis. 
visible from the front studio that reminds one of what was once there. ${ }^{17}$ It was a place that had a history and life of its own separate from the front studio, one where photographs of a range of Zanzibari persons and places were developed, printed, and came into material existence on paper. Here I develop the darkroom as a place of photographic complexity and not just mechanical reproduction, following Candice Jansen's fascinating recent work on South African 'darkroom girls. ${ }^{18}$ As she rightly points out, the darkroom as a material space for the production of photographs is largely forgotten in histories of photography. What visual images are left out with our almost exclusive focus on the photographer and the final print as opposed to the technician? It was he, she or they who often made crucial decisions to develop a certain roll of film, shade or darken certain areas or persons within the edges of the photograph, or produce a particular print. ${ }^{19}$ As well, if we zoom in on a particular African darkroom (such as Oza's, wherein he happened to be both technician and photographer), we realise that each has its own photographic assemblage that returns us to the history of photography and its foundational basis in concepts of dark (absorption) and light (reflection) in the service of image-making. In other words, it is important to expand our thinking of a photographic darkroom beyond its physical space to be a place or rather site of crossings where specific images happened, and were made to happen, and with Zanzibar made representable as an island space through the medium of photography. ${ }^{20}$

The darkroom then becomes a sight for analysis and interpretation on its own, replacing the front rooms of history and photography in some sense. It is a site where important decisions are made by photographers and/or technicians involving printing, developing, cropping, editing, formatting and reproduction. Can we also think of the chemical and watery processes of print-making (inside the darkroom) which work as a palimpsest to expose images, and as paralleling in some sense Zanzibar's island relationship to a surrounding Indian Ocean? Does one stand in for or blur the other, a form of thinking, seeing, and developing images through relationality on the part of Oza, as akin to the way he envisioned and experienced living in Stone Town, and on the island of Zanzibar?

17 The original darkroom was located directly behind where the front counter is at Capital Art Studio, so that Ranchhod could easily close its door in order to attend to customers queuing in the front room, according to Rohit Oza. He pointed out where the old darkroom of his father used to be during our visit in 2015. Rohit continued to develop film, negatives and prints in that same darkroom after taking over his father's studio from 1983 onwards, and including after his father's death in 1993. It was in the early 2000 s that he decided to move the darkroom offsite to an undisclosed location, with no additional details forthcoming from Rohit, unfortunately. Pamila Gupta with Rohit Oza, Stone Town, Zanzibar, 17 July 2015.

18 See C. Jansen, 'Dark Room Girls' (Draft paper), presented at the Humanities Graduate Centre, Wits University, Johannesburg, South Africa, 15 May 2018. I would like to credit Candice Jansen with sparking the idea of thinking and writing about the photographic darkroom in relation to Capital Art Studio.

19 Very often it is the known photographer who owns the camera and takes the photographs, whilst behind the scenes, an often unnamed, unknown technician develops the roll of film, cuts the negatives, and produces the contact sheets for the named photographer, who chooses which images to print, display and disseminate in the press. Here, once again, it is Candice Jansen's work (a former PhD student at WiSER under my supervision alongside Sarah Nuttall) on the contact sheet as a forgotten medium of photography (akin to the darkroom) that is important. See C. Jansen, 'Coloured Black: The Life \& Works of South African Photographers: Ernest Cole \& Cedric Nunn' (PhD dissertation, WiSER/Department of Art History, University of the Witwatersrand, Johannesburg, South Africa, 2020).

20 I would like to thank Phindi Mnyaka for this point from her discussant comments at the 'Other Lives of the Image' conference at UWC in Cape Town, South Africa, 4 October 2019. She followed up on Greg Dening's musing on beaches as sites of crossings where things happen and are made to happen, as applicable to the photographic darkroom. See G. Dening, Beach Crossings: Voyaging across Times, Cultures and Self (Philadelphia: University of Pennsylvania Press, 2004). 
Lastly, the photographic darkroom can be thought of as a sensorium-filled space of talking and touching, sociality, secretions, liquid substances and smells, all taking place in the dark it must be remembered. For the case of Capital Art Studio, it was a space where a father (Ranchhod) and son (Rohit) were both photographers and technicians, working side by side and developing both prints and their relationship with one another. Here we might expose the darkroom to be a site of sociality and kin networks, of technological development and reproducibility as well. The photographic darkroom can be conceived as a political and politicised space; by bringing it into sharper focus, it becomes an agentive space of history-making, a testament to which versions of history, including which subjects, objects and ideas will be given material existence in some sense, will come to be visualised for a future moment. Just as a photographic print reverses the dark and light-filled sections of a negative, there is a flipping here from the front to the back, to the objectness and subjectness of the darkroom. Can we push these ideas even further to potentially think about fieldwork - including my research visits to Zanzibar, my own photographic practices, and the back-stories narrated to me by Rohit Oza of his father - as a sort of darkroom to my ethnographic reflections and refractions cohered here? ${ }^{21}$ This second section is an experiment in the dark.

\section{Part III: Beauty in/of the Dark: Sky and Water}

Zanzibar was historically situated as a nexus point for East African, Indian Ocean, Mediterranean, Persian, Arab and Atlantic trade networks. Goods, people and ideas circulated within this globalised space and regional 'island hub', Zanzibar being a frequent stopping-off point and involving different sets of rulers, first the Portuguese (1498-1698), and then the Omani Arabs (1698-1964) alongside the British (18901963), who made Zanzibar a protectorate and part of their colony of Tanganyika until the latter's independence of $1961 .{ }^{22}$ Jeremy Prestholdt emphasises Zanzibar's historic 'unusual cultural vibrancy', stating that

relatively few ports in the world have commanded an unrivalled relationship with such a vast hinterland as Zanzibar in the nineteenth century. The island capital functioned as an intermediary between the greater East African region, stretching from Lake Malawi to the eastern Congo and southern Somalia, and ports as distant as Boston, Istanbul, Calcutta and Canton. ${ }^{23}$

21 I developed this idea of fieldwork as a darkroom of sorts in the context of reading Elisabeth Cameron's chapter, 'The Fieldworker and the Portrait: The Social Relations of Photography', in J. Peffer and E. Cameron (eds), Portraiture \& Photography in Africa (Bloomington: Indiana University Press, 2013), 141-73. In her compelling chapter, Cameron reflects on her own photographic practices in the field whilst studying women's visual practices in Zambia, which in turn made me reflect on my own as well as other ethnographic activities (as a processing lab for ideas) in the context of writing about visual cultures in Zanzibar.

22 See B. Schnepel and E. Alpers (eds), Connectivity in Motion: Island Hubs in the Indian Ocean World (Cham, Switzerland: Palgrave Macmillan, 2018).

23 See J. Prestholdt, 'Zanzibar, the Indian Ocean, and Nineteenth-Century Global Interface', in Schnepel and Alpers, Connectivity in Motion, 138. 
In this third section, I develop the trope of darkness as a form of beauty visualised in certain images of sky, water and skin from this island photographic archive. Here darkness is an aesthetic, hue, mood and affect.
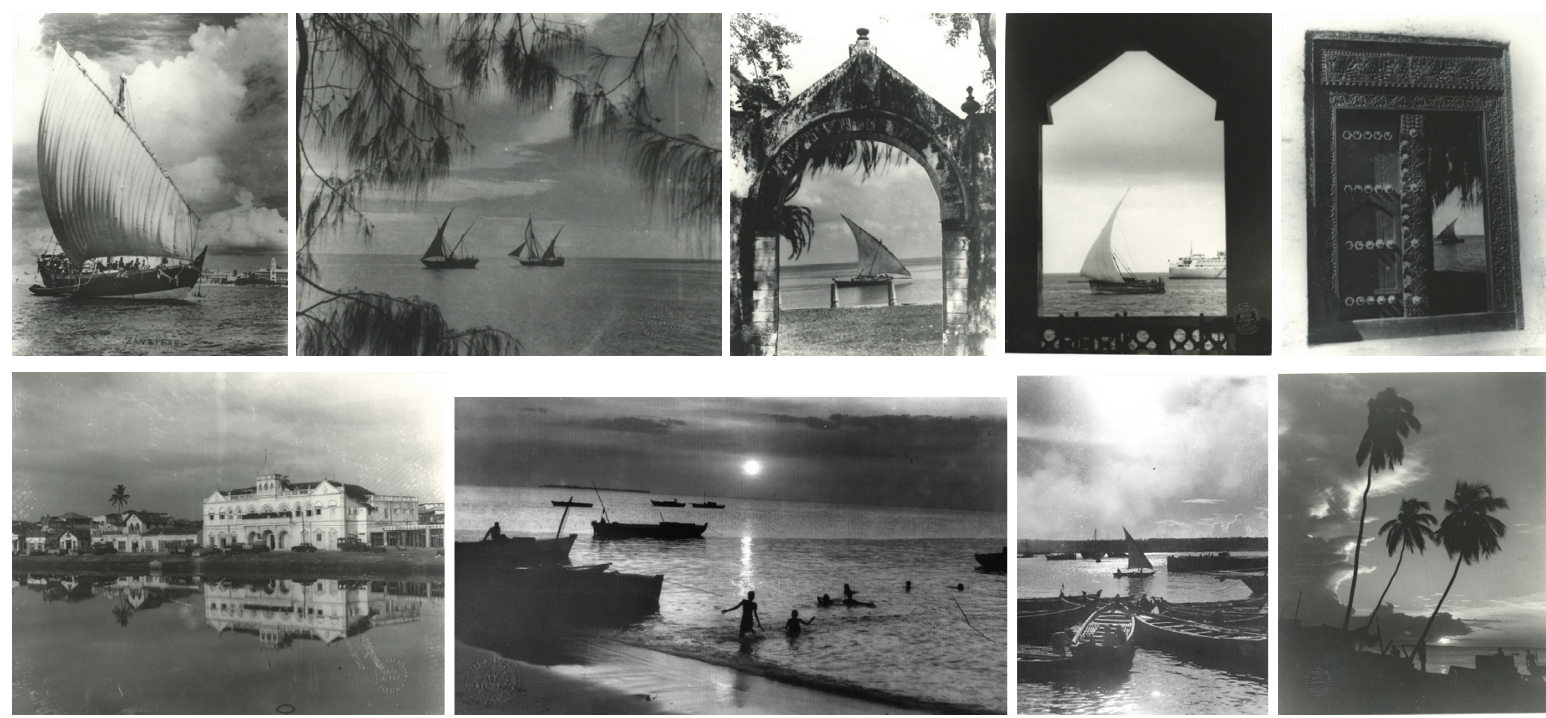

The first set of photographs of sky and water that I have culled from the Capital Art Studio collection enable a viewpoint of Zanzibar's historical position as an Indian Ocean port city, and do so through a framing lens of darkness and lightness. My focus is on the final print, even as I am aware of Ranchhod Oza's darkroom techniques (of shading, darkening, lightening, cropping, cutting, developing, printing, and superimposition which he played around with later in life) that make possible a Capital Art Studio archive of photographs. There exist numerous images of a luminous Indian Ocean, one where sky and water consistently split the photograph, sometimes unevenly, reflecting off one another and incoming light, of depth, breadth and difference, including framing Zanzibari carved wooden doors, and cumulus clouds wafting in a patterned monsoonal sky. Just as islands are surrounded by water and are constantly flooded by light from all sides, they are also highly photographable for these same reasons. Ranchhod Oza was a skilled photographer who took advantage of both photography's elemental traits and Zanzibar's islandness, as well as the fact that ocean and sky are both mediums that reflect light powerfully, to produce images of Zanzibar's palm trees, sunsets and cliffs, including their watery reflections. The darkness of the water surrounding the island is set up in contrast to the lightness of the sky in many of these images.

These images of sky and water also showcase the famous dhow of Zanzibar, ${ }^{24}$ and gesture to these specialty boats (and cultural symbol) as dependent on the winds, cross-currents and clouds to circulate people and things, bringing slaves, spices and

24 See A. Sheriff, Dhow Cultures of the Indian Ocean: Cosmopolitanism, Commerce, and Islam (London: C. Hurst \& Co., 2010). 
ivory from Africa to Europe, ${ }^{25}$ with its white bright lateen canvas sails suggesting a lightness of being - of travel, worldliness and mobility in an earlier era. At the same time, the stuff of these dhows implicates darkness; the ripples of waves they produced as they cut through dark choppy waters suggest Zanzibar's longer history of slavery, a trafficking in black bodies that crossed or drowned, some meeting their watery submerged futures in the act of arriving in this port city via the Indian Ocean. ${ }^{26}$ Ranchhod went so far as to create iconic images of Zanzibari islandness for tourist consumption, relying on the dhow to do so. Included here is one such photograph produced in the 1950s wherein Ranchhod superimposed a dhow onto the empty waters of the Indian Ocean, perfectly framed by the famed sixteenth-century Portuguese arch in Stone Town, built to mark their presence and control of the island.

Probing deeper then for the other multiple lives embedded in this set of images of sky and water from the Capital Art Studio collection highlights Zanzibar's islandness, its sense of placeness in a flourishing twentieth-century Indian Ocean world, its position as a stopping-off point for sailors, traders, merchants, members of the Omani Sultan's royal family, and British colonial officials, its complicit history in the global trade of slaves, and finally its stark monsoonal beauty. Perhaps these photographs of sky and water produced by Ranchhod Oza of an island and taken on an island during a particular historical time frame (1930s-60s) can be pushed even further, to say something more about photography as occupying or rather filling in Zanzibar's Indian Ocean islandness, and vice versa, a reading offered from this contemporary early twenty-first-century moment of a global pandemic that has restricted if not completely stopped all travel and tourism to islands such as Zanzibar, and finally an ongoing anthropocentric crisis of climate change that will only worsen with time to make these same places less sustainable for residents and visitors alike. ${ }^{27}$

\section{Part IV: Beauty in/of the Dark: Skin}

Next I focus on a set of photographic prints from the Capital Art Studio collection that showcase the beauty of black skin, and which differentiate varying shades of darkness,

25 By the middle of the eighteenth century, Zanzibar had become a considerable depot for the expansive African slave trade, only ending with its legal formal abolition under the British (and by agreement with the Omani Sultanate Seyyid Barghash bin Said earlier in 1873) in 1897; those slaves then became labourers and squatters working under a plantation economy, their conditions of life and work barely improved. For an expanded history of Zanzibar's slave, spice and ivory trade under British colonial rule, see A. Sheriff, Slaves, Spices, and Ivory in Zanzibar: Integration of an East African Commercial Empire into the Word Economy, 1770-1873 (Athens, OH: Ohio University Press, 1987); A. Sheriff, Zanzibar under Colonial Rule (Oxford: James Currey, 1991).

26 During the period 1800 to 1876 , the number of slaves arriving on the east coast of Africa increased from 6000 a year to an estimated peak of 30,000 annually between 1870 and 1876 . These figures give some sense of the scale and numbers of slaves arriving in Africa via the Atlantic and Indian Oceans. See E.B. Martin, Zanzibar: Tradition and Revolution (Zanzibar: Gallery Publications, 2007), 32. Tied into thinking the Indian Ocean as a place of darkness is the idea of kala pani (Hindi for "black water'), as a darker name given to this body of water - its crossing and passage from India to Africa considered a religious taboo by many Hindu Indian immigrants arriving in East Africa during the late nineteenth and early twentieth centuries. This, however, did not deter Ranchhod Oza from leaving Gujarat and arriving in Zanzibar in 1925 via these same circuits. See R. Ebr.-Vally, Kala Pani: Caste and Colour in South Africa (Cape Town: Kwela Books, 2001).

27 I am thankful to Phindi Mnyaka for her provocative discussant comments at the 'Other Lives of the Image' conference hosted by UWC's Visual History and Theory project under the direction of Professor Patricia Hayes, where I presented an earlier draft of this paper, 3-4 October 2019. She pushed me to think about photography as occupying islandness, and vice versa, which adds a layer to my discussion here and ties into my earlier work. See P. Gupta, 'Islandness in the Indian Ocean', in P. Gupta, I. Hofmeyr and M. Pearson (eds), Eyes Across the Water: Navigating the Indian Ocean (Pretoria: Unisa Press, 2010). 

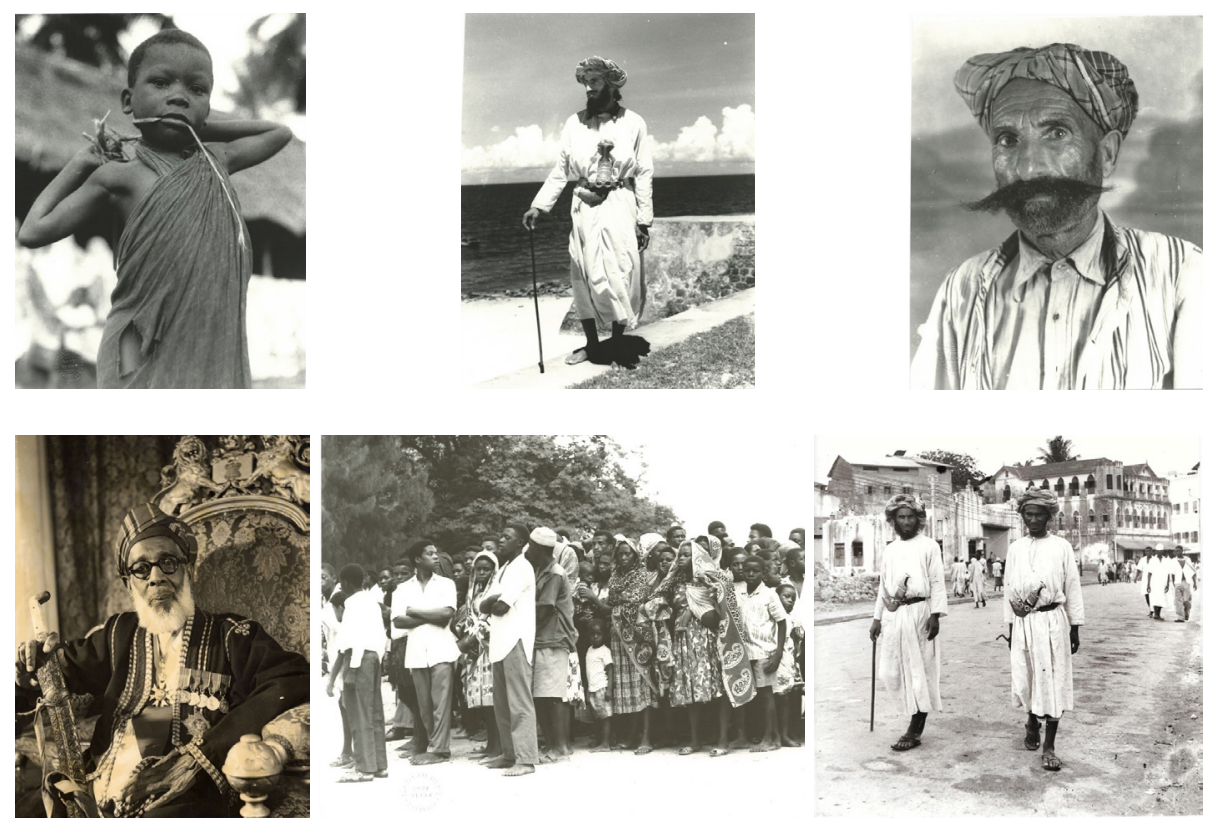

as opposed to the dull greyness of human skin. ${ }^{28}$ Here it is important to conceptualise darkness as both 'an aesthetic as well as social concept that operate in visual tension with each other. ${ }^{29}$ In other words, darkness in relation to skin lends itself to multiple simultaneous readings, as always involving categories and value judgements on race. It is potentially a thing of beauty or ugliness and can easily go either way for the viewer. Again, my focus is on the material photograph, but I am still interested in keeping in mind the way certain darkroom technologies (of lighting, the setting of exposure times, zooming) were employed by Ranchhod Oza to differentiate a range of skin tones in these photographs, and against and across a range of bright daytime ${ }^{30}$ and dark night-time settings which showcase Zanzibar's entwined British Protectorate and Omani Sultanate status. Oza was well trained in darkroom processing and technologies, as is evidenced in his many acts of portraiture. If we think of portraits as light based' images, ${ }^{31}$ then we are perhaps made more aware of the photographic techniques he employed both outside and inside the darkroom to signal the beauty of darkness. They include heightening the black of black skin, giving light to dark faces, and high-

28 Relevant is the history of the grey card in photographic practice for setting the white balance, and the way it was used as the norm to set up the lighting and correct aperture/shutter speed on the camera, the implication being that it was set up for white skin tones. I look forward to reading Drew Thompson's fascinating forthcoming work on the history of Polaroid film and black skin tones.

29 I take this idea from John Peffer's discussion of Candice Keller's work on Bamakois portrait photography. See his 'Introduction: The Study of Photographic Portraiture in Africa, in J. Peffer and E. Cameron (eds), Portraiture \& Photography in Africa (Bloomington: Indiana University Press, 2013), 22.

30 I read Oza’s images and imaging as working very much against the whiteness and brightness of certain British colonial settings and figures, the whiteness of white skin and white colonial uniforms that would have been the subjects for colonial photography during this same era.

31 John Peffer emphasises this often-forgotten point in his 'Introduction: The Study of Photographic Portraiture in Africa', in J. Peffer and E. Cameron (eds), Portraiture \& Photography in Africa (Bloomington: Indiana University Press, 2013), 23. 
lighting textures, creases and folds. ${ }^{32}$ This set of portraits is quite remarkable in my mind, as they represent the reality of a cosmo-politan Zanzibar, including a range of figures and personalities that passed through this thriving port city engaged in trade or business from the 1930 s to early 1960 s, prior to its revolution.

Certain portraits made by Ranchhod Oza of a range of Zanzibari figures stand out: the young African boy with the taut smile and intent gaze, the bright billowing folds of an Omani sailor's kaftan, the wrinkled skin and curvaceous moustache on a weathered Pakistani Baluchi sailor, an aged Sultan Khalifa wearing his royalty with faded pride, a lively crowd of people -including men, women and children - watching a dhow race off camera, and finally, a casual street scene with all manners of people, age and dress crossing paths. Oza illuminates a range of skin tones in these photographs - of Africans, Asians and Arabs - while at the same time showing the complexity of facial features that enable viewers such as myself to move beyond the blankness of race to visualise Zanzibaris as islander individuals.

In the act of reading Ranchhod's images of dark skin for their other lives in the here and now, during a global time and movement of 'Black Lives Matter', I am invested in reading them for indexing a larger global history of the photography of black skin and bodies, starting with the psycho-analytics of inhabiting blackness from Frantz Fanon in 1952. ${ }^{33}$ I am reminded of Robert Mapplethorpe's censored photographs of the late 1980s I witnessed and that transform black skin into marble sculptures, ${ }^{34}$ a thing of beauty. ${ }^{35}$ Here, however, we must also reckon with Kobena Mercer's important argument that Mapplethorpe's ability to photograph (black) bodies as if they were marble or bronze sculptures also continued a centuries-long tradition of separating black physicality from black subjectivity. ${ }^{36}$ Mercer's point returns us in some sense to Michelle Wright's work gestured to earlier on the physics of blackness wherein instantiations of blackness constantly need to be situated in specific time/place contexts. Closer to home, I am reminded of South African photographer Zanele Muholi's recent set of self-portraits (Somnyama Ngonyma, Hail the Dark Lioness, 2018) that show the luminosity of her own black skin. ${ }^{37}$ Can we consider a range of imaging of these kinds of photographs of black bodies and skin from Oza through to Muholi as a form of 'visual activism'? ${ }^{38}$ Finally, I read this set of images through the lens of

32 By extension, I ask if the same could be said for what he does to photograph white skin for this British African colonial setting? Does Oza make complex white skin to the extent that he does for black skin? I would argue that white skin is often more bleached out in his images, simplified in some sense. This is less my focus here, but it would be a point to develop further.

33 F. Fanon, Black Skin, White Masks (New York: Grove Press, 1967 [1952 French edn]).

34 As an undergraduate studying photography in the US (at the University of Virginia), I have a distinct memory of standing in a very long line in order to see the controversial exhibit ('Robert Mapplethorpe: The Perfect Moment') which was on display in Philadelphia at the Institute of Contemporary Art (ICA) in 1988.

35 Here I want to think about 'beauty' in more expansive terms. See U. Eco (ed), On Beauty: A History of a Western Idea (London: Vintage UK, 2004).

36 See K. Mercer, 'Reading Racial Fetishism: The Photographs of Robert Mapplethorpe', in Welcome to the Jungle: New Positions in Black Cultural Studies (London: Routledge, 1994).

37 Zanele Muholi's book and photograph exhibit which I attended is entitled 'Dark Lioness'; it is also telling as it plays with the 'Africa as the heart of darkness' trope. See Z. Muholi, Somnyama Ngonyma, Hail the Dark Lioness (Johannesburg: Stevenson Art Gallery, 2018).

38 Zanele Muholi has described herself as a 'visual activist'. See M. Schwendener, 'Review: Zanele Muholi, a Visual Activist, Presents “Isibonelo/Evidence", New York Times, 14 May 2015, https://www.nytimes.com/2015/05/15/arts/design/reviewzanele-muholi-a-visual-activist-presents-isibonelo-evidence.html. I am activating her term to expand the photographic canon to include lesser-known (African) photographers like Ranchhod Oza. 
Krista Thompson's writings on photography on and of the tropics of the Caribbean, which could be likened to the tropics of Zanzibar as an island nation of intense heat, humidity, beauty, light, darkness and bodily earthy sweat. Thompson writes of the sheen and shine of black skin aesthetics, and the role of specialty lighting in showing off the beauty of blackness through photography, a detail and skill perhaps not lost on Ranchhod Oza even as he was working in an East African context, and at an earlier historical moment, and thus more reliant on natural lighting, but to similar effect and affect. ${ }^{39}$ Returning to our theme of the other lives of photographs, these images of a range of dark skin tones produced by Oza of a diverse island population once again point to the role of photography as occupying or rather filling in Zanzibar's Indian Ocean islandness, and vice versa.

\section{Part V: A Time of Photographic Darkness}

Several years into establishing Capital Art Studio in Stone Town, Ranchhod Oza became the official photographer for Omani Sultan Khalifa bin Haroub, a relationship that continued with his family members after the latter's death in 1960 and until the Sultanate was deposed in the Revolution of 12 January 1964, a momentous event for the people and history of Zanzibar. Ranchhod had taken all of the Sultan's official photographs over a 30-year span, including of royal events and family portraits. With the Revolution, the unification of the Zanzibar islands of Unguja (again, which includes Stone Town), Pemba and Tumbatu alongside mainland independent Tanganyika took place, together becoming the nation-state of Tanzania. ${ }^{40}$ In this last section, I conceptualise the Zanzibar Revolution of 1964 as a time of photographic darkness. Here darkness is a temporality, climate, mood, political moment and ideology, a form of restricting visuality in terms of the photographic. For many Zanzibari islanders, particularly its minority Goan, Parsi and Gujarati immigrant communities that had arrived in Stone Town via the Indian Ocean and continued to look outward, they did not fully support the Revolution, including its forced integration alongside mainland Tanganyika to become a unified nation-state. Instead, for some (including Oza) it was considered akin to a time of political darkness, one of chaos, killings, massacres, secrecies and sudden departures of Arabs and Indians, certain lesser-known aspects of the Revolution that William Bissell and Marie-Aude Fouéré have described with historical depth..$^{41}$ Interestingly, the Revolution itself was started in the dark of night of 11-12 January $1964,{ }^{42}$ a detail that is important to the layered story of darkness I am telling here.

39 See K. Thompson, An Eye for the Tropics (Durham: Duke University Press, 2006) and Shine: The Visual Economy of Light in African Diasporic Aesthetic Practice (Durham: Duke University Press, 2015).

40 For a general overview of the events leading up to and the history of the Revolution, see O. Mapuri, Zanzibar: The 1964 Revolution: Achievements and Prospects (Dar es Salaam: TEMA Publishers); J. Glassman, War of Words, War of Stones: Racial Thought and Violence in Colonial Zanzibar (Bloomington: Indiana University Press, 2011); G. Mwakikagile, The Union of Tanganyika and Zanzibar: Formation of Tanzania and its Challenges (Dar es Salaam: New Africa Press, 2016).

41 W. Bissell and M. Fouéré, Social Memory, Silenced Voices, and Political Struggle: Remembering the Revolution in Zanzibar (Dar es Salaam: Mkuki na Nyota Publishers, 2019). As they suggest, the history and meaning of the Revolution are sharply contested by all those involved, and are still being remembered, archived and made sense of.

Ibid., 42. 

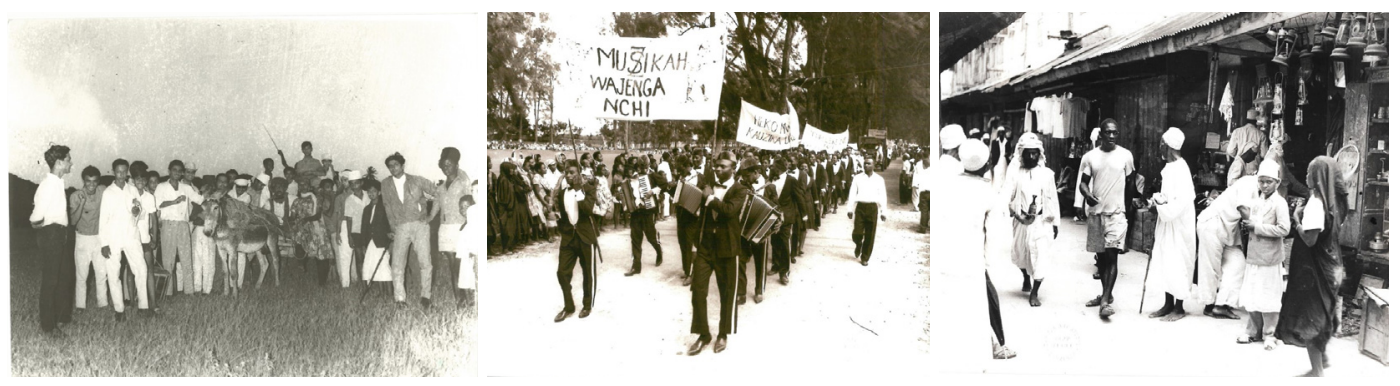

For Ranchhod Oza, the time of the Revolution was initially one of personal hardship, a shifting political climate, but also one of slow acceptance of historical change taking place on his home island. All photography studios in Stone Town viewed by the new Tanzanian government as in support of the Sultan were immediately shut down in the days following the Revolution. Capital Art Studio, including its physical darkroom, managed to endure. Rohit tells me that his father was first forced to remove the portrait of Sultan Khalifa holding pride of place on his studio wall, a difficult thing to do considering that the Omani leader, husband and father had become his close friend through their photographic relationship. Rohit has a distinct memory of his father during these tumultuous times: it is of him burning all the Sultanate images (both prints and negatives) in sight inside the studio walls, as a 14-year-old son quietly watched from the sidelines. ${ }^{43}$ Despite all these strict measures, Ranchhod astutely managed the political transition post-Revolution, keeping his photography studio open while the last two remaining ones closed shop, including that of his mentor Goan photographer A.C. Gomes. According to Rohit, his father was forward thinking, and from this moment of acceptance, was involved in taking photographs of and documenting Afro-Shirazi Party rallies, visiting socialist dignitaries to Zanzibar (from Africa, the Eastern bloc, including the former East Germany and China) and everyday life in a changing Stone Town. Ranchhod was even able to put up his own portrait of the new nationalist leader, Abeid Karume, to replace that of Khalifa that he had been forced to remove. ${ }^{44}$

Zanzibar thus experienced a time of visual darkness in that photography practices were temporarily restricted under the new Afro-Shirazi political party in the postRevolution period. ${ }^{45}$ As public photography had been officially banned, many chose the cover of darkness to take photographs, including John Da Silva, a Goan Zanzibari photographer whom I met in 2012 in Stone Town. He recounted his own story as a young man at the time of the Revolution, of climbing the rooftops of Stone Town's buildings, furtively taking photographs at night, to document what was happening in

45 While my focus is on photography as temporarily restricted in the aftermath of the Revolution, film-making took on a different role. For a fascinating reading of the controversial Italian documentary film Africa Addio (1966), which includes a disturbing sequence of footage shot over the first few days after the Zanzibar Revolution showing hundreds of dead bodies, and which was used widely by European colonial nostalgic propaganda to suggest the inability of Africans to govern themselves, see M. Fouéré, 'Africa Addio, the Revolution, and the Ambiguities of Remembrance in Contemporary Zanzibar', in Bissell and Fouéré, Social Memory, 311-34. The film (translated as 'Africa Blood and Guts' for US audiences) functioned as a retrograde apologia for European colonialism, reverting back to a sense of Africa as the 'heart of darkness' in Conrad's terms. 
front of his camera lens, in the hopes of producing a visual record of historical events as they unfolded. ${ }^{46}$ As well, during this period, any and all photographs of Zanzibar's Omani Sultanate presence were destroyed in an attempt to forget history, including its rich visual past, one full of images of dark and light, black and white, sky, water and skin, and tropical island beauty, images that I have showcased here, but produced largely at the expense of its African indigenous and former slave populations. We must keep in mind that for the majority of Zanzibaris, the Revolution was a time of political lightness, the opening up of Zanzibar to its mainland connections, a return to its African roots, political power no longer held in the hands of a small Arab ageing elite population propped up by a sagging British colonial state, and where its own governmental strictures of silence, suffering and suspicion had also taken place. Once again, tropes of darkness and lightness can be used to read this polarising political moment, to shed light on history in the making, the suppression of certain images and the production of new ones, alongside acts of visual remembering and forgetting.

Meanwhile, Rohit took over the running of the studio nearly 20 years after the Revolution, in 1983, once Ranchhod formally retired from the work of photography, living a full life with occasional visits to the studio now under the proud proprietorship of his son, until his death in $1993 .{ }^{47}$ Rohit carries on his late father's photographic practices, continuing to (re)print and (re)produce images made by Ranchhod of past light and dark-filled moments during its tumultuous history. He also leaves hanging the photograph of Karume taken by Ranchhod in the front room of Capital Art Studio, perhaps in an act of homage to him. During one of my visits, Rohit tells me the story of how his eldest brother had earlier moved to London in 1962 and inadvertently taken many of their father's negatives and prints with him, which, in light of the Revolution, were accidently saved and the start of the Capital Art Studio archival collection. This same brother now maintains all the Capital Art Studio negatives there in cold storage, and is the keeper of Ranchhod's archive. I would argue that Rohit plays an equally important role, as the keeper of his father's images, including their future other lives.

Rohit himself has extended and created another distinct life for a certain set of his father's images, going so far as to retake images of a street that his father photographed 50 years earlier, documenting its physical changes in the interim, and selling both sets of offprints (a sort of before and after) to newly arrived groups of visitors who stop in at Capital Art Studio as part of its position as a popular heritage and tourist destination. Rohit also produces his own contemporary images of Zanzibar, including portraits from inside the Capital Art Studio, bullfights on the nearby island of Pemba - a particular interest of his - family weddings and special occasions, political rallies, and press photos for ZIFF, the annual Zanzibar International Film Festival that takes place every July in Stone Town.

Pamila Gupta and Meg Samuelson with John Da Silva, Stone Town, Zanzibar, 20 October 2012. Sadly, Da Silva passed away on 20 March 2013 at the age of 76 .

47 Ranchhod Oza went back to Gujarat in 1990 for a last family visit, and fell ill there. It was Rohit who by the early 1980 s had taken over the running of Capital Art Studio on a daily basis after his father's retirement. It was he who travelled to Gujarat to get his father in the early 1990s; it was Rohit's first trip to India. He brought back a frail man who never fully recovered. Yet Ranchhod had lived a happy and fulfilled life, and died a happy man in 1993, Rohit tells us. Pamila Gupta and Meg Samuelson with Rohit Oza, Stone Town, Zanzibar, July 2015. 


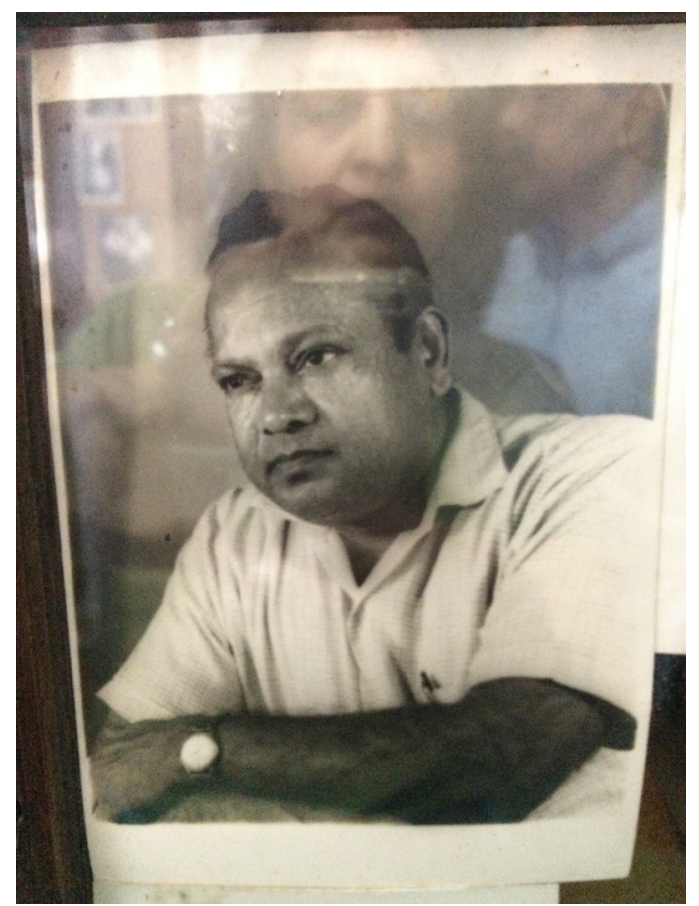

Courtesy of Rohit Oza who kindly granted permission to reprint his father's images from the Capital Art Studio archive in 2018.

Returning to the idea of the physical darkroom, I would often ask Rohit where he prints his images now. It is a question that he evades answering. For even as Rohit no longer uses the old defunct darkroom that was once located behind the now faded front curtain, he still produces prints from his father's negatives somewhere else, a darkened place undisclosed to me despite numerous attempts to find out its precise location. As well, with the global turn to the digital, Rohit has followed suit for his own image-making via a digital camera that he always carries with him. More generally, Rohit's photographs continue to reflect Zanzibar's Indian Ocean island heritage with touristic images of sunsets, beaches and local residents, while others situate its much-changed geography, as a semi-autonomous region within Tanzania. He adds yet another layer to Zanzibar's photographic islandness, all the while gesturing to the other multiple lives of his father's images unfurling, much like a dhow's canvas sails during the monsoon winds, into an unseeable future tense.

I end this meditation on darkness with a photograph that I took inside Capital Art Studio on my last visit to Zanzibar in 2018. It is a photograph of a rare photograph of Ranchhod Oza that Rohit shows me one day, and that I decide to photograph for the purposes of my own image-making. In looking at my final print, and by fortuitous accident, I notice that both Rohit and I appear as faint presences in the lightened spaces of the photograph framing the central figure of Ranchhod Oza, a seemingly content middle-aged husband, father and studio proprietor. The photograph works as a palimpsest, gesturing to Zanzibar's photographic islandness that I have written about and approached through a trope of darkness, the accumulated layers of dismembered time from Ranchhod to Rohit through to myself, and finally, the multiple other lives that all photographs have the potential to carry inside them. 